\title{
Role of Endogenous Bone Marrow Stem Cells Mobilization in Repair of Damaged Inner Ear in Rats
}

\author{
Ahmed M. Elbana ${ }^{1}$, Seddik Abdel-Salam¹, Ghada M. Morad², Ahmed A. Omran ${ }^{1}$ \\ Departments of ${ }^{1}$ ORL-HEN Surgery, ${ }^{2}$ Histology, Faculty of Medicine, University of Alexandria, Alexandria, Egypt
}

\begin{abstract}
Background and Objectives: The utilization of the stem cells is widely used in the last few years in different fields of medicine, either by external transplantation or endogenous mobilization, most of these studies still experimental on animals; few were tried on human as in the spinal cord injury or myocardial infarction. As regard its use in the inner ear, stem cell transplantation was examined in many previous studies, while the mobilization idea is a new method to be experimented in inner ear hair cell regeneration. The present work assessed the possibility of mobilizing endogenous bone marrow derived stem cells (SCs) in rats using granulocyte colony stimulating factor (G-CSF) to induce regeneration and repair to experimentally damaged inner ear hair cells by Amikacin injection.

Methods: The study included thirty adult Sprague Dawley male rats. Experimental induction of inner ear damage was done by repeated intratympanic injection of amikacin sulfate. Mobilization of bone marrow SCs was provoked by subcutaneous injection of GCSF. Cochlear integrity, induction of hearing loss and functional recovery of sensory hearing loss were assessed using Distortion Product Otoacoustic Emission (DPOAEs). The morphological alteration and recovery of the organ of Corti was assessed histologically using the light and scanning electron microscopes. Results: After six month duration, there was improvement in 50\% of the sensorineural DPOAE results. Functional recovery coincided with the repair of structural components of organ of Corti.

Conclusions: SCs mobilization by G-CSF is a promising alternative method for replacement therapy in sensorineural hearing loss.
\end{abstract}

Keywords: Stem cells, Mobilization, Inner ear, Rats, Hearing, Amikacin

\section{Introduction}

The inner ear is composed of two main parts. The auditory portion includes the cochlea, which is involved in hearing, and the vestibular system which is involved in

Accepted for publication August 31, 2015, Published online November 30, 2015 Correspondence to Ahmed M. Elbana

Department of ORL-H\&N Surgery, Faculty of Medicine, University of Alexandria, Egypt. King Fahd Military Medical Complex P.O.Box.No-946 Dhahran-31932 Kingdom of Saudi Arabia Tel: +966504875923, Fax: +966138405555

E-mail: ahmedelbanna@yahoo.com

(a) This is an open-access article distributed under the terms of the Creative Commons Attribution Non-Commercial License (http://creativecommons.org/ licenses/by-nc/4.0/), which permits unrestricted non-commercial use, distribution, and reproduction in any medium, provided the original work is properly cited. balance. Our ability to hear and our sense of balance are critically dependent on specialized sensory receptors called hair cells, these cells have structures called stereocilia, which sense sounds by bending back and forth, converting mechanical vibrations into electrical, or neural signals that are then passed to the brain through the auditory nerve (1-3).

Finding ways to cure deafness represent a major scientific and clinical breakthrough. Recently, stem cells from the inner ear of adult mice have been identified (4). These adult stem cells are found in the utricle of the vestibular region of the inner ear. They have the characteristic features of stem cells such as the capacity for self renewal and expansion (they divide and multiply). They form spheres, which begin to differentiate into new cell types termed as progenitor cells. Some progenitor cells differ- 
entiate into cells that express proteins and genes present in the developing inner ear and nervous system. Under appropriate conditions, some cells differentiate into cells resembling hair cells, which have stereocilia; hair bundles protruding from their surface and express specific hair cell marker proteins. The discovery of such cells is a first step toward a promising line of treatment in restoring hearing and balance function $(5,6)$.

Stem cells are unspecialized cells that have two defining properties: the ability to differentiate into other cells and the ability to self-regenerate $(6,7)$.

There are two main types of stem cells: embryonic and adult stem cells. Embryonic stem cells are derived from embryos. Unlike adult stem cells, embryonic stem cells can become all cell types (pluripotent) (8-11).

Adult stem cells are stem cells that can be derived from different parts of the body and, depending on where they are from, have different properties. They exist in several different tissues including bone marrow, blood and brain. Some studies have suggested that adult stem cells are very versatile and can develop into many different cell types (12-23).

From a scientific perspective, scientists will first need to identify compounds and conditions that can increase the growth of stem cells and promote their differentiation into hair cells or supporting cells (24). From a clinical perspective, surgical and technical procedures need to be developed to successfully transplant stem cells into the inner ear. The critical question to be answered is whether transplanted stem cells can migrate to the correct location, differentiate into hair cells and restore hearing or balance $(25,26)$.

Mobilization of endogenous stem cells provides an alternative way of replacing damaged inner ear hair cells, and correcting hearing loss $(19,22)$. Mobilizing host stem cells is less cumbersome than transplantation in that it avoids the logistical complexity associated with the use of embryonic as well as non embryonic stem cells, including supply, surgical trauma, and possibilities of graft rejection, uncontrolled graft cell proliferation and tumor formation.

\section{Aim}

The aim of this work was to assess the use of G-CSF (Granulocyte Colony Stimulating Factor) to mobilize Bone Marrow Stem Cells to reach the inner ear of rats and its ability to repair damaged inner ear by Amikacin sulfate.

\section{Materials and Methods}

Thirty adult male Sprague-Dawley rats were supplied by the Veterinary Department of Medical Research Institute, University of Alexandria. They were housed and manipulated according to the work protocol approved by the Research Ethics Committee, Faculty of Medicine, Alexandria University.

All rats were examined under microscopic magnification for the tympanic membrane to exclude any ear abnormalities and then subjected to DPOAEs for assessment of cochlear integrity and exclusion of rats with sensorineural deficits.

Rats were randomly divided into two groups: Group A consists of 15 rats which were dissected and the inner ear was histologically examined as a negative control for the other injected group. Group B consists of 15 rats which were subjected to the following:

1) Intra-tympanic injection under microscopic magnification with Amikacin sulfate at starting dose of $5 \mathrm{mg} / \mathrm{kg}$ bilaterally in 10 rats and unilaterally in 5 rats.

2) DPOAE of all injected rats (Group B) was done to assess the hearing function 3weeks after first Amikacin injection.

3) Intra-Tympanic Amikacin injection was repeated until we had negative DPOAE of all injected rats (Group B) at 3, 6 and 9 weeks after first injection.

4) Subcutaneous injection of GCSF (Granulocyte Colony Stimulating Factor) at a dose of 200 microgram $/ \mathrm{kg} /$ day for 5 successive days for 10 rats of the 15 rats injected with Amikacin (Group B). The other 5 rats were kept untreated with GCSF as positive control (hearing damaged by Amikacin but not treated with GCSF).

5) One month after GCSF treatment all rats were examined with DPOAEs to assess the hearing function and the same was repeated every month till 6 months.

6) Dissection of 2 rats was done every month one of each group and the inner ear was histologically examined. And after the follow up period of 6 months, all the remaining rats were dissected and the inner ear was histologically examind by:

- Light microscopic examination of paraffin sections using routine hematoxylin and eosin (H\&E) stain (17).

- Scanning electron microscopic examination of specimens (SEM) by Joel scanning electron microscope 5-25 $\mathrm{KV}$, Electron Microscopy Unit, Faculty of Science, University of Alexandria (18). 


\section{Results}

\section{Audiological Results}

The onset for developing a negative DPOAE record (becoming deaf) in experimented rats treated with amikacin sulfate showed individual variation. Six rats became DPOAE negative three weeks after the first intratympanic injection, while another 6 rats following the second injection became deaf. The remaining 3 rats became DPOAE negative nine weeks later, and received a third dose with three weeks interval from the second amikacin injection.

Eight rats (out of ten) survived to the end of the experiment among the group treated with GCSF simultaneously with amikacin sulfate. They did not show any improvement in the DPOAE records during the first two months of the experiment.

By the end of the third month, 2 rats revealed improvement of the sensorineural hearing functions as indicated by shift of their DPOAE records from negative to positive. Four months from starting the experiment, another rat exhibited a positive shift in the DPOAE assessment. By the end of the fifth month and the sixth month, 4 rats revealed a shift to a positive DPOAE in both ears.

Three rats treated with amikacin sulfate without GCSF survived to the end of the experiment. They exhibited persistent negative DPOAE records.

Table 1 illustrates the statistical analysis of the 6 months follow up DPOAEs assessment according to the number of experimented rats shows that $50 \%$ of the rats with amikacin sulfate induced hearing loss revealed statistically significant recovery of the sensorineural hearing function six months after treatment with GCSF $(p \leq 0.046)$ (Table 1).

\section{Histological Results}

The negative control rats demonstrated a normal organ of Corti with typical structural organization (Fig. 1). The sensory epithelium was formed of hair cells arranged in an inner and several outer rows (Fig. 2) with intact apical

Table 1. 6 months follow up DPOAEs assessment according to Rats number

\begin{tabular}{|c|c|c|c|c|c|c|c|c|c|c|c|}
\hline & \multicolumn{2}{|c|}{ M1 } & \multicolumn{2}{|c|}{ M2 } & \multicolumn{2}{|c|}{ M3 } & \multicolumn{2}{|c|}{ M4 } & \multicolumn{2}{|c|}{ M5 } & M6 \\
\hline & No. & $\%$ & No. & $\%$ & No. & $\%$ & No. & $\%$ & No. & $\%$ & No. \% \\
\hline- ve & 8 & 100.0 & 8 & 100.0 & 6 & 75.0 & 5 & 62.5 & 4 & 50.0 & $4 \quad 50.0$ \\
\hline+ ve & 0 & 0.0 & 0 & 0.0 & 2 & 25.0 & 3 & 37.5 & 4 & 50.0 & $\begin{array}{ll}4 & 50.0\end{array}$ \\
\hline $\mathrm{p}$ & & & & 000 & & 57 & 0.0 & 83 & 0.0 & $46 *$ & 0.046* \\
\hline
\end{tabular}

$\mathrm{p}: \mathrm{p}$ value for McNemar test.

*Statistically significant at $\mathrm{p} \leq 0.05$. stereocilia (Fig. 7A). The normal arrangement of the rows of inner and outer hair cells was demonstrated in the peculiar architecture of the reticular lamina of the cochlea as seen by the SEM (Fig. 7B).

The intratympanic injection of amikacin sulphate caused almost complete destruction of the cellular elements forming the organ of Corti as compared to normal structure

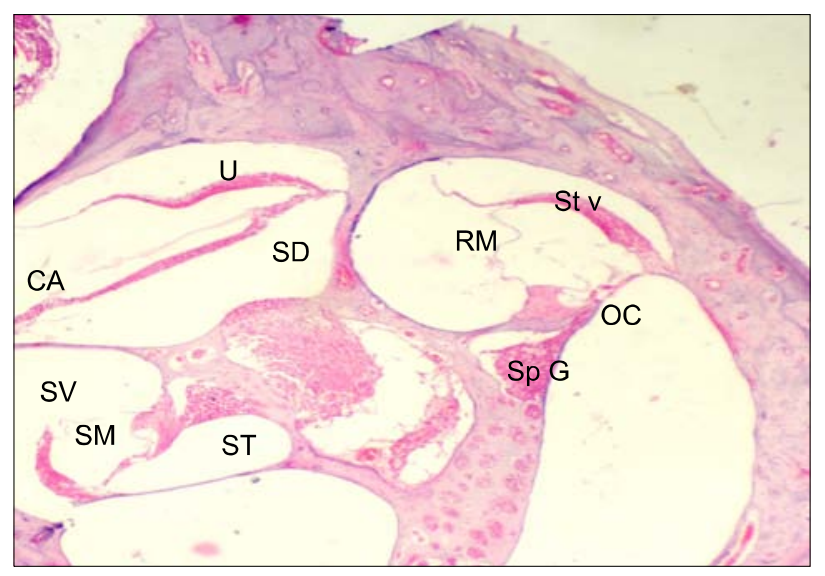

Fig. 1. Light photomicrographs of control rat inner ear cavity demonstrating the cochlear cavity divided by Reissener's membrane (RM) into scala media (SM) and scala vestibule(SV). The organ of Corti (OC) intervenes between the scala media and the scala tympani (ST). It is bounded laterally by the stria vascularis (St V) and medially by the spiral ganglion (SG). The semicircular duct (SD) shows the macula utriculi $(U)$ and the crista ampullaris (CA) (H\&E stain. Mic. Mag. $\times 40$ ).

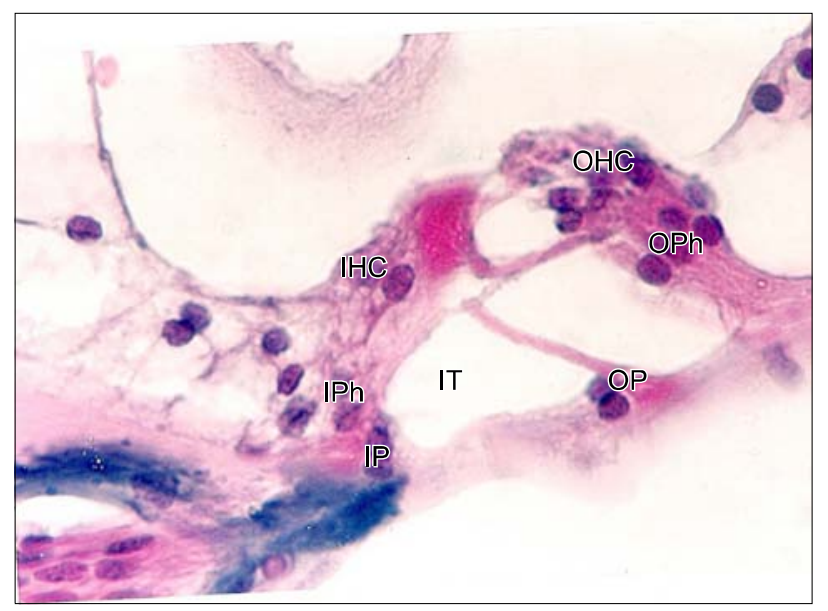

Fig. 2. Higher magnification of the cellular components of the control organ of Corti demonstrating: A single row of inner hair cells (IHC) supported by the underlying inner phalangeal cells (IPhC), and several rows of outer hair cells $(\mathrm{OHC})$ supported by the outer phalangeal cells (OPhC). The inner tunnel (IT) is bounded between the inner (IP) and outer pillar (OP) cells (H\&E stain. Mic. Mag. $\times 1000)$. 

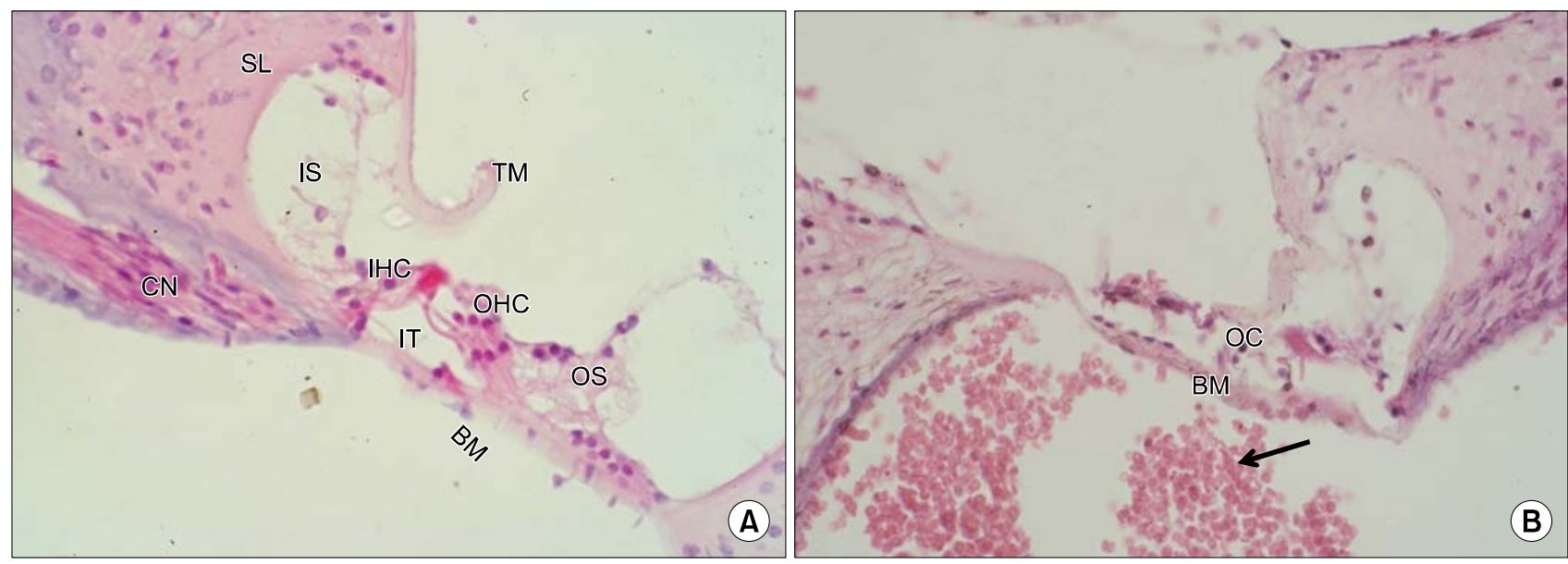

Fig. 3. (A) Light photomicrographs of control rat Organ of Corti showing: The main structural components including the spiral limbus $(\mathrm{SL})$, tectorial membrane (TM), inner supporting cells (IS), inner hair cells (IHC), inner tunnel (IT), outer hair cells (OHC), outer supporting cells (OS), basilar membrane (BM) and the related cochlear nerve (CN). (B) An OAE negative rat (deaf), 6 months after administration of amikacin revealing destruction of the organ of Corti (OC), disappearance of the inner and outer supporting cells and infiltration of the cochlear cavity by red blood corpuscles (arrow). Note the intact basilar membrane (BM) (H\&E stain. Mic. Mag. $\times 400)$.

(Fig. 3A and B). However, the basilar membrane remained intact (Fig. 3B). The stereocilia of the hair cells were totally destroyed (Fig. 7C) thus leaving empty indentations within the reticular lamina of cochlea (Fig. 7D). In addition, there was an evident infiltration of the inner ear cavities with red blood corpuscle (Fig. 3B and 7C).

The vestibular structures of a normal control rat inner ear (crista and macula) histologically had no significant changes after Amikacin injection (Fig. 4) and this indicates that its main effects were on the cochlear structures and 6 months after GCSF therapeutic regimen the stria vascularis (Fig. 5A) reveals a complete sheet of intact superficial epithelium with residual interstitial vacuolation in the supporting connective tissue stroma. Also we can see intact macula utriculi (Fig. 5B) and intact crista ampullaris (Fig. 5C). Also we can see intact spiral ganglion (Fig. 5D).

Histological examination of inner ear specimens from rats receiving GCSF therapeutic regimen confirmed the regeneration of the organ of Corti that coincided with the positive shift of the DPOAE records of these rats.

The earliest histological sign for the onset of regeneration of the organ of Corti in the GCSF- treated rats was observed as appearance of aggregates of morphologically non specific cells on top of the intact basilar membrane (Fig. 6A). After 2 months from receiving the GCSF therapeutic regimen, the scala media demonstrated a group of supporting-like cells that settled over the surface of the basilar membrane (Fig. 6B). Two months later (4 months from receiving GCSF), a primitive organ of Corti could be depicted. Rows of inner and outer hair cells with the intervening tunnels could be recognized (Fig. 6C). By the end of the sixth month from receiving GCSF therapeutic regimen, most of the examined H\&E sections revealed almost full reconstruction of the organ of Corti. The detailed structural components were identifiable, including a well formed tectorial membrane and a patent tunnel of Corti supported by rigid, intact pillar cells (Fig. 6D).

\section{Discussion}

The use of Stem Cells in the repair of damaged inner ear was first tried by Ito et al. in 2001 using neural stem cells (19). And also in 2003 they studied the fate of neural stem cells grafted into injured inner ears of mice (20).

In $2003 \mathrm{Li}$ et al. have identified stem cells from the inner ear of adult mice. These adult stem cells are found in the utricle of the vestibular region of the inner ear (21). This discovery has opened the door for many other researchers to explore the utilization of stem cells in the inner ear repair and restoration of hearing function.

Heller et al. in 2003 have studied the generation of hair cells by stepwise differentiation of embryonic stem cells (22). And Parker et al. in 2004 studied the potential use of stem cells for cochlear repair $(23,24)$. Also many other stem cell studies have done in the next few years between 2003 and 2010 but most of these studies concentrated on the transplantation of stem cells into damaged inner ear or in vitro studies for generating hair cells from stem cells of different origins $(25,26)$. 

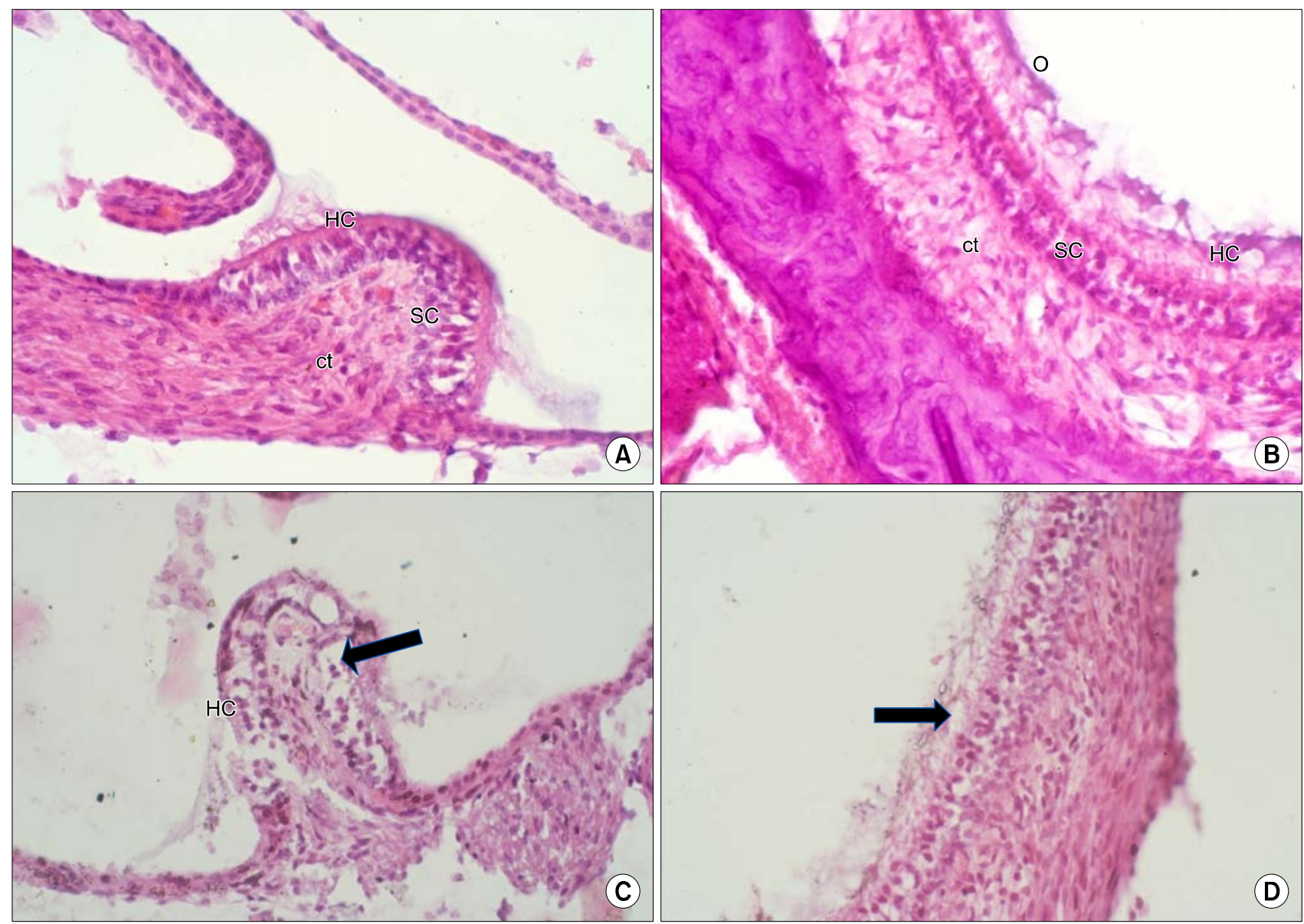

Fig. 4. (A) The crista ampullaris shows an intact superficial layer of hair cells (HC) supported by an underlying layer of supporting cells (SC) and connective tissue stroma (ct). (B) The macula utriculi show an intact superficial layer of hair cells (HC) and the overlying otoconia (O). It is supported by a deeper layer of supporting cells $(\mathrm{SC})$ and connective tissue stroma (ct). (C, D) Light photomicrograph of OAE negative rat, 6 months after injection with amikacin: The crista ampullaris reveals vacuolation and widening of interstitial spaces between hair cells and supporting cells (thick arrow). Note that many hair cells (HC) are still intact. The macula utriculi show intact layers of hair and supporting cells (arrow) (H\&E stain. Mic. Mag. $\times 400)$.

The idea of mobilization of bone marrow stem cells is a new idea and it was proved to be successful in many other fields of medicine, in 2006 Zohlnhöfer et al. proved its use in acute myocardial infarction to replace the damaged cardiomyocytes. Also Kloner et al. tried its use on human in 2006 in attempts to recruit stem cells for repair of acute myocardial infarction $(27,28)$.

Mobilization of stem cells by GCSF also utilized in acute cerebral ischemia by Schabitz et al. in 2003 and by Shyu et al. in 2006 in acute ischemic stroke $(29,30)$.

Also it was tried to use GCSF to mobilize bone marrow stem cells in retinal damaged photoreceptors by Oishi et al. in 2008 and in a model of Parkinson's disease by Meuer et al. in 2006 and in many other fields (31, 32).

At the beginning of the study we had to make sure of the hearing ability of all rats because some genetic malfor- mations may exist in rats similar to humans which is not uncommon, so we used Electrophysiological study which is a portable Oto-acoustic emission (OAE) as a screening tool for hearing function and the rats which were negative were excluded before the start of the study.

We used aminoglycosides (Amikacin sulfate) to cause cochlear damage to the rat's inner ear because it have a more cochlear side effect than vestibular unlike Streptomycin and Gentamicin which are the most commonly used drugs in the past studies but their effect is more vestibular than cochlear.

Amikacin sulfate was injected via Intra-tympanic approach not via systemic approach to avoid its systemic nephrotoxic effect which may have killed our rats before the follow up period of the study, and also to allow rapid toxic effect on the inner ears. And this was carried out 

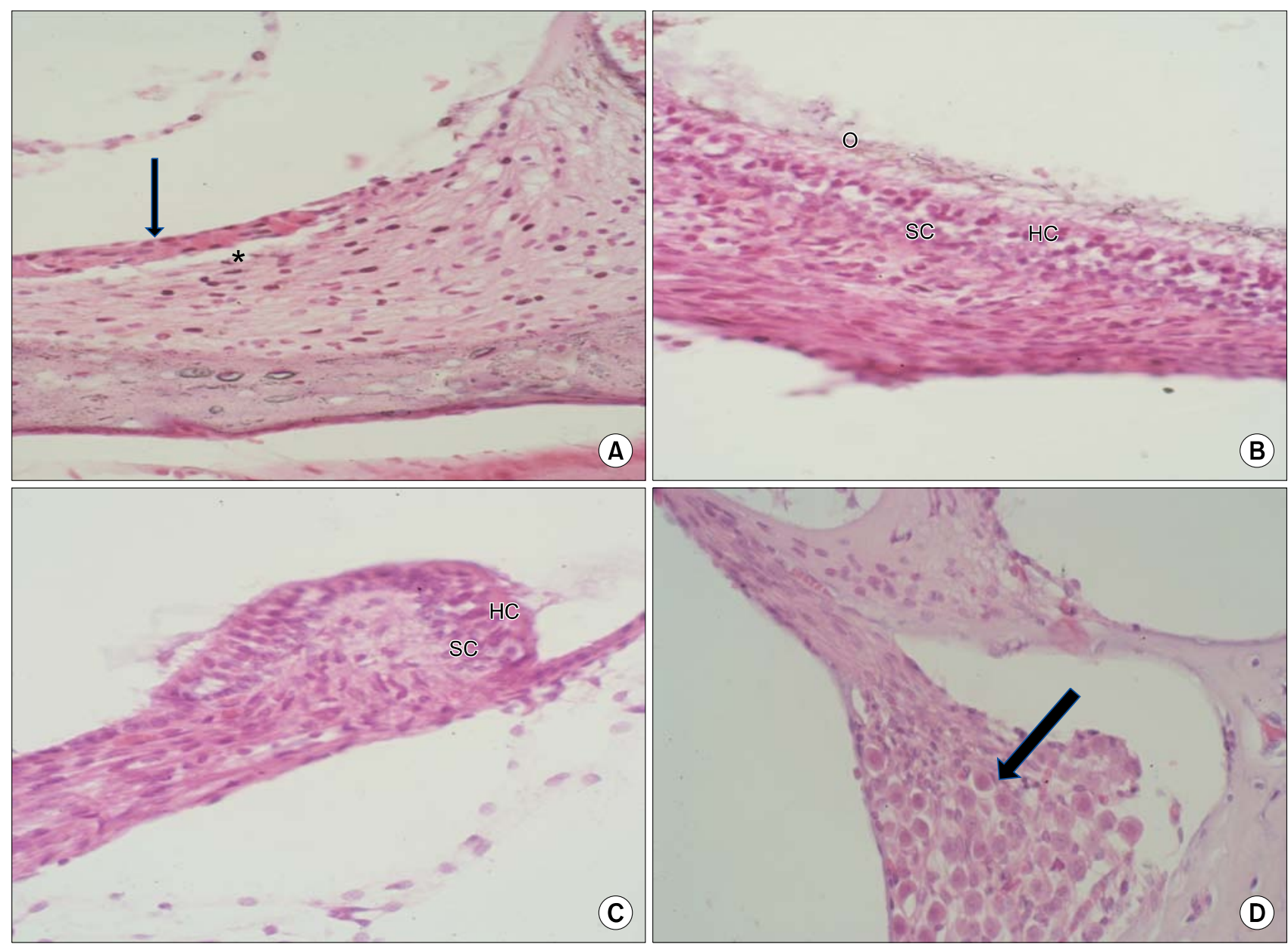

Fig. 5. (A) The stria vascularis of rat recovering after GCSF therapeutic regimen reveals a complete sheet of intact superficial epithelium (arrow) with residual interstitial vacuolation in the supporting connective tissue stroma $(*)$. (B) The macula utriculi of a rat recovering after GCSF therapeutic regimen show intact structural components: $(\mathrm{HC})$ hair cells, $(\mathrm{SC})$ supporting cells, $(\mathrm{O})$ otoconia. $(\mathrm{C})$ The crista ampullaris of rat recovering after GCSF therapeutic regimen shows intact layers of hair cells (HC) and supporting cells (SC). (D) The spiral ganglion of rat recovering after GCSF therapeutic regimen (arrow) is composed of intact bipolar cells with apparently average cell density (H\&E stain. Mic Mag. $\times 100)$.

under microscopic magnification.

Amikacin injection was repeated until we had negative OAEs of all injected rats and this was reached in all rats after 9 weeks of the first Amikacin injection.

Some rats were injected with Amikacin bilaterally and others were injected unilaterally, in the rats with unilateral injection the contralateral ears were used as a control to have the same conditions and reduce the inter-animal variability.

We used a 5 day therapeutic regimen of subcutaneous injection of GCSF and the dose according to previous publications in literature in humans is $5 \sim 10 \mathrm{Microgram} / \mathrm{kg} /$ day but in rats it is $100 \sim 200 \mathrm{Microgram} / \mathrm{kg} /$ day (16).

One month after GCSF treatment the rats were examined with DPOAEs to assess any improvement in the hear- ing function and the same was done every month till 6 months.

After 6 months follow up we had 4 rats (5 ears) which were negative OAEs became positive OAEs showing clinical improvement in hearing function.

The group which was bilaterally injected with Amikacin we had 2 rats ( 3 ears) improved after GCSF treatment after a total follow up period of 6 month while in the group which was unilaterally injected with Amikacin we had improvement in 2 rats (2 ears).

The positive control group (Rats which were bilaterally injected with Amikacin but did not treated with GCSF) remains negative OAEs after the same follow up period of 6 months and this indicates that there was no spontaneous improvement in hearing function over this period of time. 


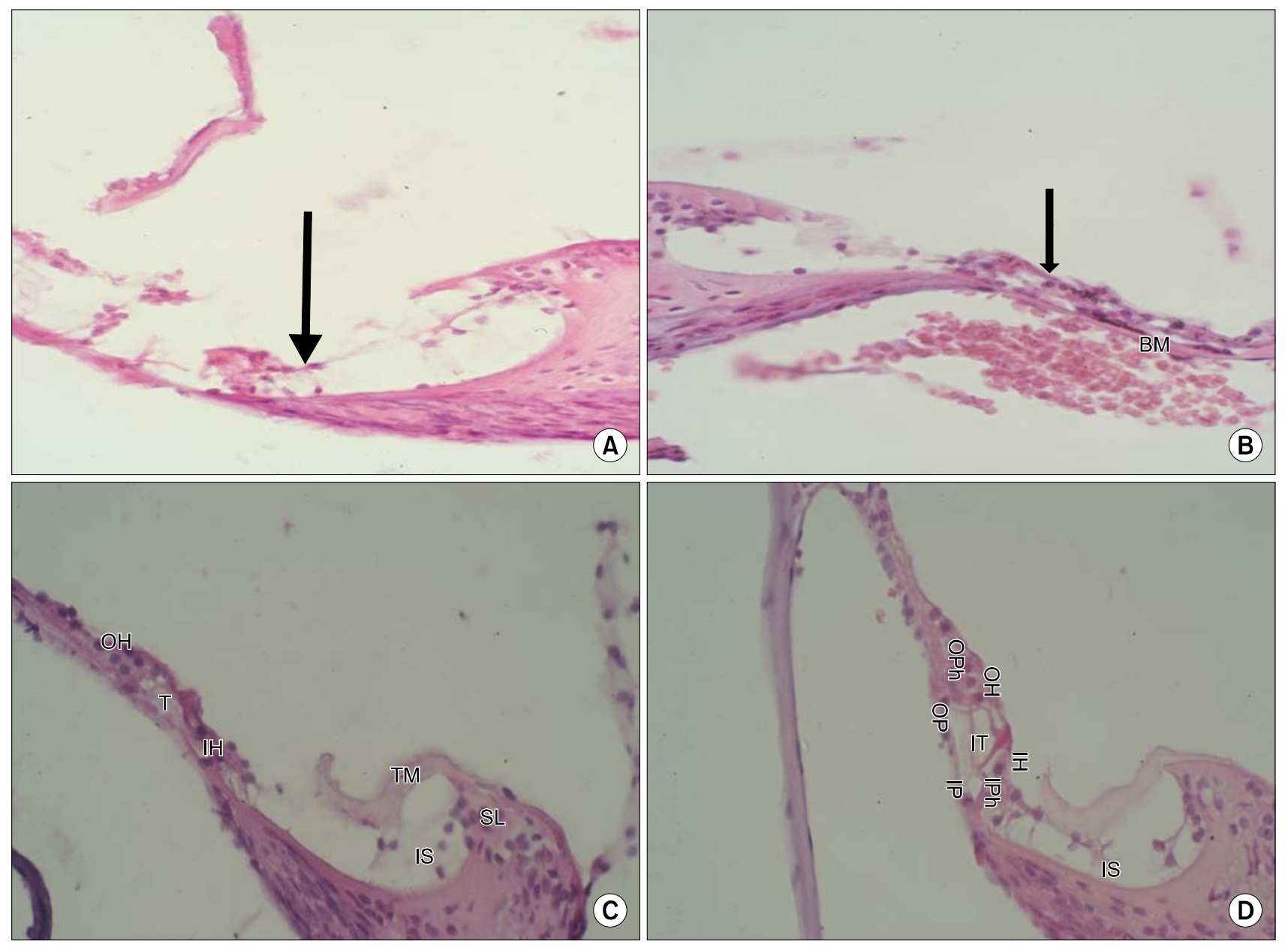

Fig. 6. (A) Light photomicrographs of organ of Corti of OAE positive rats recovering within variable durations from receiving GCSF therapeutic regimen: After 4 weeks, the organ of Corti shows few outer hair cells (arrow). No other cellular components of the organ of Corti are identifiable. (B) After 8 weeks, the scala tympani reveals group of cells (arrow) that are apparently organized into a primitive Organ of Corti. $\mathrm{SL}=$ spiral limbus, BM=basilar membrane. (C) After 12 weeks, the organ of Corti is formed of well structured rows of inner supporting cells (IS), inner hair cells $(\mathrm{IH})$, outer hair cells $(\mathrm{OH})$ and the intervening tunnels $(\mathrm{T})$. SL=spiral limbus, TM=tectorial membrane. (D) Light photomicrographs of the inner ear from OAE positive rats recovering after 24 weeks from receiving GCSF therapeutic regimen: showing a normal, fully structured organ of Corti composed of intact rows of outer hair cells $(\mathrm{OH})$, outer pillar cells (OP) and an intact row of inner hair cells $(\mathrm{IH})$ supported by inner pillar cells (IP). The outer (OPh) and inner (IPh) phalangeal cells border the inner tunnel (IT). (IS) inner supporting cells $(\mathrm{H} \& \mathrm{E}$ stain. Mic Mag. $\times 400)$.

Histological comparison was done between the inner ear of normal rats and the inner ear of Amikacin injected rats and showed that the damage was more cochlear in the form of destruction of Organ of Corti and disappearance of the inner and outer supporting cells and hair cells.

After treating Amikacin injected rats with GCSF, histological examination was done on variable durations and showed improvement in the arrangement of hair cells till we reached complete restoration of Organ of Corti after 6 months and this was consistent with the clinical results of OAEs.

While histological examination of the positive control rats (which were injected with Amikacin and not treated with GCSF) showed no improvement and this was also consistent with the clinical results.

\section{Conclusion}

In conclusion, knowledge of the structure, molecular biology and function of the inner ear enables the research on new modes of regenerative therapies. Currently, the majority of these means remain at an experimental level. The present work has achieved its primary aim in proving the possibility for recruitment of progenitor cell diffentia- 

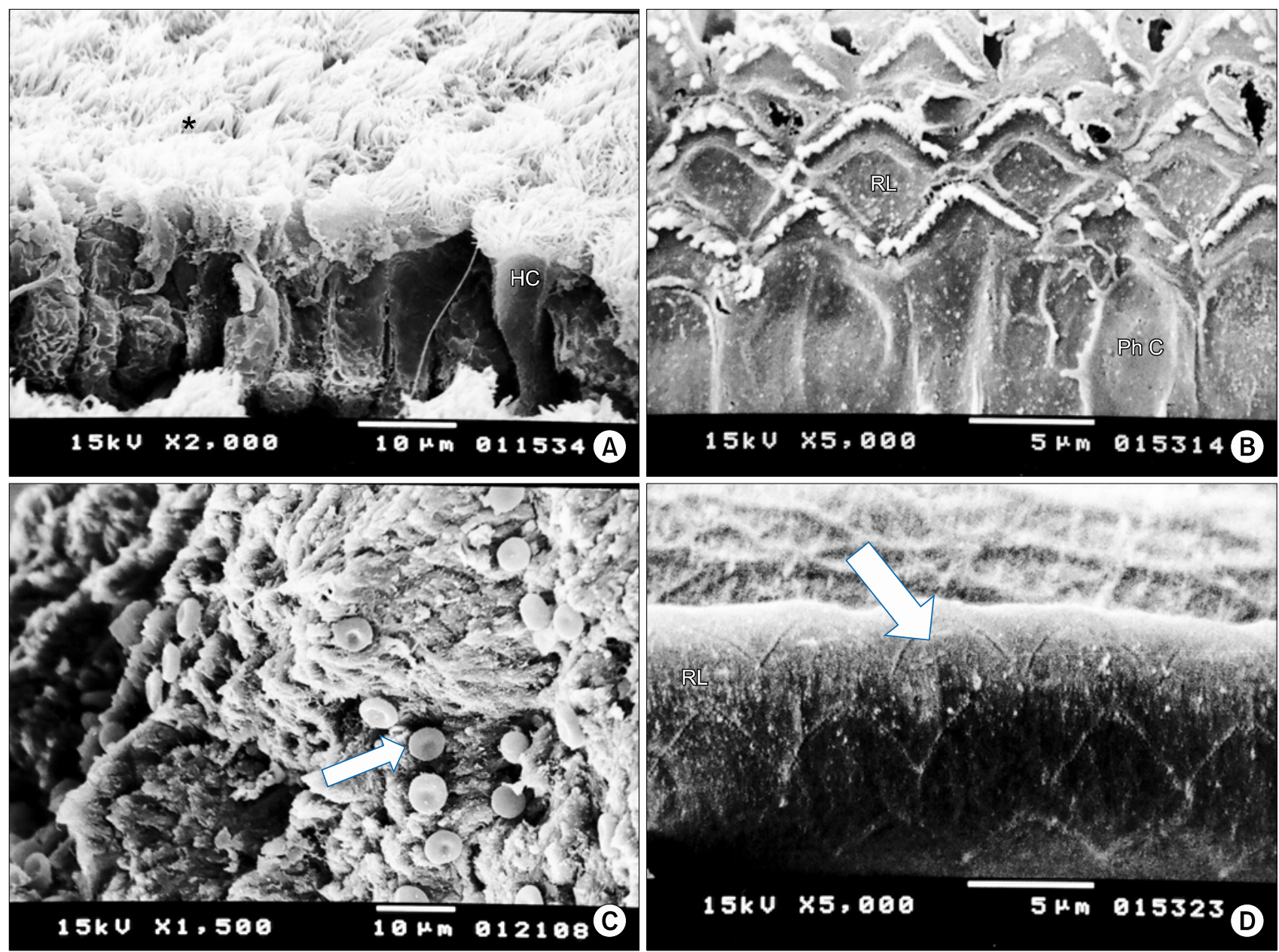

Fig. 7. (A) Scanning electron photomicrograph of control rat organ of Corti demonstrating: Normal hair cells (HC) with intact stereocilia $(*)$ projecting from their apices. (B) Surface view of the reticular lamina $(\mathrm{RL})$ showing three parallel rows of intact stereocilia of the outer hair cells. (Ph C) bodies of supporting outer phalangeal cells. (C) Scanning electron photomicrographs of the cochlear cavity in an OAE negative (deaf) rat, 6 months after injecting amikacin: The cochlear cavity is infiltrated by many red blood cells (arrow). No details of hair cells neither of its stereocilia can be identified. (D) Surface view of the reticular lamina (RL) of the organ of Corti showing parallel rows of empty indentations (arrow) marking the lost outer hair cells (Mic. Mag. $\times 5000$ ).

tion into hair cells and supporting cells within the organ of Corti by using granulocyte colony stimulating factor therapy. The study of the histology of the obtained result in correlation to the $\mathrm{OAE}$ testing proved the morphological and functional competence of the regenerated cells.

Based upon the obtained results, it is recommended to expand research in this issue using different animal models to evaluate species dependent variations. Evaluation of the delayed systemic effects and possible hazards of GCSF therapy should be also investigated. Monitoring of the sensorineural hearing integrity should involve both quantitative and qualitative acoustic measurement. Advanced investigation should be applied that allow quantitative evaluation of the recruited bone marrow derived stem cells together with application of specific techniques for tracing, characterization and monitoring of the fate of these cells.

\section{Potential conflict of interest}

The authors have no conflicting financial interest.

\section{References}

1. Gulya AJ, Anson BJ. Anatomy of the ear and temporal bone. In: Shambaugh GE, Glasscock ME III, editors. Surgery of the ear. 5th ed. Hamilton: B.C. Decker Inc.; 2003. 35-57

2. Gulya AJ, Schuknecht HF. Anatomy of the temporal bone with surgical implications. 2nd ed. Pearl River, NY: Parthenon Pub Inc.; 1995.

3. Anson BJ, Donaldson JA. Surgical anatomy of the temporal bone. 3rd ed. Philadelphia: WB Saunders; 1981.

4. Michaels L, Hellquist HB. Ear, nose and throat histo- 
pathology. 2nd ed. London: Springer; 2001.

5. Lim DJ. Functional structure of the organ of Corti: a review. Hear Res 1986;22:117-146

6. Weissman IL. Stem cells: units of development, units of regeneration, and units in evolution. Cell 2000;100:157-168

7. Sell S. Stem cells. Stem Cell Handbook ed. by Sell S. 2004; $1-18$

8. Blau HM, Brazelton TR, Weimann JM. The evolving concept of a stem cell: entity or function? Cell 2001;105:829841

9. Díaz-Flores L Jr, Madrid JF, Gutiérrez R, Varela H, Valladares F, Alvarez-Argüelles H, Díaz-Flores L. Adult stem and transit-amplifying cell location. Histol Histopathol 2006;21: 995-1027

10. Bryder D, Rossi DJ, Weissman IL. Hematopoietic stem cells: the paradigmatic tissue-specific stem cell. Am J Pathol 2006;169:338-346

11. Handgretinger R, Gordon PR, Leimig T, Chen X, Buhring HJ, Niethammer D, Kuci S. Biology and plasticity of CD133+ hematopoietic stem cells. Ann N Y Acad Sci 2003;996:141151

12. Wagers AJ, Christensen JL, Weissman IL. Cell fate determination from stem cells. Gene Ther 2002;9:606-612

13. Cohen Y, Nagler A. Umbilical cord blood transplantation-how, when and for whom? Blood Rev 2004;18:167-179

14. Nagler A, Bellehsen L, Schaffer F. Stem Cells: Clinical Applications. 7th ed. Adkinson: Middleton's Allergy; 2008. 259-268

15. Parker MA, Corliss DA, Gray B, Anderson JK, Bobbin RP, Snyder EY, Cotanche DA. Neural stem cells injected into the sound-damaged cochlea migrate throughout the cochlea and express markers of hair cells, supporting cells, and spiral ganglion cells. Hear Res 2007;232:29-43

16. Demetri GD, Griffin JD. Granulocyte colony-stimulating factor and its receptor. Blood 1991;78:2791-2808

17. Carletons HM, Drury RAB, Willington EA. Carleton's histological technique. 5th ed. Oxford: Oxford University Press; 1980. 43

18. Glauert AM. Fixation, dehydration and embedding of biological specimens. 1st ed. Amsterdam, Oxford: North Holland Pub; 1986. 111-114

19. Ito J, Kojima K, Kawaguchi S. Survival of neural stem cells in the cochlea. Acta Otolaryngol 2001;121:140-142

20. Tateya I, Nakagawa T, Iguchi F, Kim TS, Endo T, Yamada S, Kageyama R, Naito Y, Ito J. Fate of neural stem cells grafted into injured inner ears of mice. Neuroreport 2003; 14:1677-1681

21. Li H, Liu H, Heller S. Pluripotent stem cells from the adult mouse inner ear. Nat Med 2003;9:1293-1299

22. Li H, Roblin G, Liu H, Heller S. Generation of hair cells by stepwise differentiation of embryonic stem cells. Proc Natl Acad Sci U S A 2003;100:13495-13500

23. Parker MA, Cotanche DA. The potential use of stem cells for cochlear repair. Audiol Neurootol 2004;9:72-80

24. Martinez-Monedero R, Oshima K, Heller S, Edge AS. The potential role of endogenous stem cells in regeneration of the inner ear. Hear Res 2007;227:48-52

25. Li H, Corrales CE, Edge A, Heller S. Stem cells as therapy for hearing loss. Trends Mol Med 2004;10:309-315

26. Pellicer M, Giráldez F, Pumarola F, Barquinero J. Stem cells for the treatment of hearing loss. Acta Otorrinolaringol Esp 2005;56:227-232

27. Zohlnhöfer D, Ott I, Mehilli J, Schömig K, Michalk F, Ibrahim T, Meisetschläger $\mathrm{G}$, von Wedel J, Bollwein $\mathrm{H}$, Seyfarth M, Dirschinger J, Schmitt C, Schwaiger M, Kastrati A, Schömig A; REVIVAL-2 Investigators. Stem cell mobilization by granulocyte colony-stimulating factor in patients with acute myocardial infarction: a randomized controlled trial. JAMA 2006;295:1003-1010

28. Kloner RA. Attempts to recruit stem cells for repair of acute myocardial infarction: a dose of reality. JAMA 2006; 295:1058-1060

29. Schäbitz WR, Kollmar R, Schwaninger M, Juettler E, Bardutzky J, Schölzke MN, Sommer C, Schwab S. Neuroprotective effect of granulocyte colony-stimulating factor after focal cerebral ischemia. Stroke 2003;34:745-751

30. Shyu WC, Lin SZ, Lee CC, Liu DD, Li H. Granulocyte colony-stimulating factor for acute ischemic stroke: a randomized controlled trial. CMAJ 2006;174:927-933

31. Oishi A, Otani A, Sasahara M, Kojima H, Nakamura H, Yodoi Y, Yoshimura N. Granulocyte colony-stimulating factor protects retinal photoreceptor cells against light-induced damage. Invest Ophthalmol Vis Sci 2008;49:5629-5635

32. Meuer K, Pitzer C, Teismann P, Krüger C, Göricke B, Laage R, Lingor P, Peters K, Schlachetzki JC, Kobayashi K, Dietz GP, Weber D, Ferger B, Schäbitz WR, Bach A, Schulz JB, Bähr M, Schneider A, Weishaupt JH. Granulocyte-colony stimulating factor is neuroprotective in a model of Parkinson's disease. J Neurochem 2006;97:675-686 